\title{
Comparative Simulation Analysis on High Gain Bidirectional and High Step-up DC- DC Converters
}

\author{
Rajesh Thumma ${ }^{* 1}$, Veera Venkata Subrahmanya Kumar Bhajana ${ }^{* 2}$ \\ School of Electronics Engineering*1,2, \\ KIIT University, Bhubaneswar, Odisha, India* ${ }^{1,2}$. \\ rajesh.thumma@hotmail.com,rajesh.thumma88@gmail.com*1 \\ bvvs.kumarfet@kiit.ac.in, kumarbvvs@yahoo.co.in*2
}

\begin{abstract}
This article mainly focuses on a comparative analysis on high gain bidirectional and high stepup soft-switching DC-DC converters for high gain high power applications. These converters are useful for high step up and step down conversion with reduced switching losses. These converters obtain zero voltage switching turn-on and zero current switching turn-off operation of the semiconductor switches by utilizing the simple series resonant capacitor and inductors respectively. The advantages of these converters are minimized voltage and current stresses, which improves overall converter efficiency. This paper describes the operational principles of bidirectional and high step-up converters as well and their simulation evaluations were compared in order to show their effectiveness of these topologies.
\end{abstract}

Keywords - Buck, Boost, non-isolated, Zero voltage switching (ZVS), Zero current switching (ZCS)

\section{INTRODUCTION}

The bidirectional DC to DC converters are most popularly used to transfer from high voltage to low voltage and vice-versa. These converters are extensively used in many industrial applications such as uninterrupted power supply systems, hybrid electric vehicles, auxiliary supplies and battery banks for storing of energy etc. A variable inductor based bidirectional converter increases the saturation level and reduces its magnetic core size [1] of power inductor, because of variable inductor under the dynamic load variations leads to increasing the additional losses. However, the overall efficiency may reduce. A bidirectional DC-DC converter [2] implemented with the parallel connection of IGBT and MOSFETs were used to reduce conduction losses and improved the voltage gain. A loosely coupled inductor (LCI) based high power density interleaved boost converter [3] obtained improved efficiency and reduced power losses, respectively. However, the converter is cost-effective due to the $\mathrm{SiC}$ (silicon carbide) switching devices are used. A dual half bridge DC-DC converter [4-6] are obtained zero voltage switching to the semiconductor devices with the aid of leakage inductances of their high frequency transformer and snubber capacitors with the MOSFETs. They achieved a poorer efficiency, due to high switching frequency operated at higher output power levels. To choose an efficient DC-DC converters, a vast comparison of various converters is presented in [7], which are used to interface fuel cells in electric vehicles. The isolated soft switching converter achieves ZVS and ZCS with low efficiency by operating the circuit in discontinuous conduction mode (DCM) [8]. A non-isolated interleaved boost converter [9-10] achieved high gain and ZVS with the aid of coupled inductors and active clamping circuits, respectively. Furthermore, it has higher efficiency at low power and lower efficiency at high power. A cascaded buck-boost inductor in middle and cascaded buckboost capacitor in middle converters [10] are comparing their efficiency at $10 \mathrm{~kW}$ and achieved efficiency is $92 \%$.

This article presents the comparative simulation analysis on high gain bidirectional [11] and high step-up DCDC converters [12], respectively. The main intention of this paper is to evaluate the performance of DC-DC converters at different output power levels. The following section II presented the operation of high gain bidirectional and high step-up DC-DC converters as well, and then section III gives the simulation evaluations and their comparative analysis.

\section{Operation Of High Gain Bidirectional AND High STEP-Up ConVERTERS}

Fig. 1 illustrates the soft switching bidirectional converter [11]. It comprised of dual half bridges (switches $S_{1 \text { - }}$ ${ }_{4}$ ) with a simple resonant circuit $\left(L_{a}\right.$ and $\left.C_{a}\right)$ to achieve ZVS turn-on operation. The circuit operation is divided into two parts, one is boost mode and another is buck mode. In boost mode of operation at a time two MOSFETs $S_{1}, S_{3}$ and $S_{2}, S_{4}$ are turned-on and due to the resonance of $L_{a}$ and $C_{a}$, the soft switching ZVS turn-on operation is achieved for all the MOSFETs. By the way, when converter operating in buck mode, the MOSFETs $S_{1}, S_{3}$ and $S_{2}, S_{4}$ are turned-on and achieving soft switching ZVS turn-on for all the MOSFETs. Although, the ZCS turn-off obtained for the MOSFETs $S_{3}$ and $S_{4}$ in boost mode and $S_{1}$ in buck mode, respectively. 


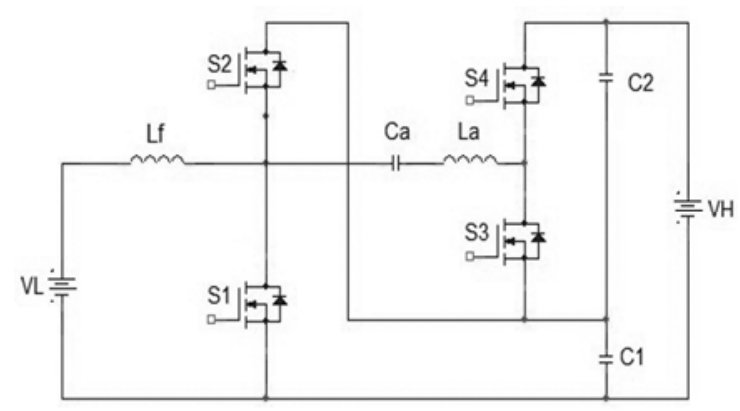

Fig. 1. High gain bidirectional DC-DC converter [11]

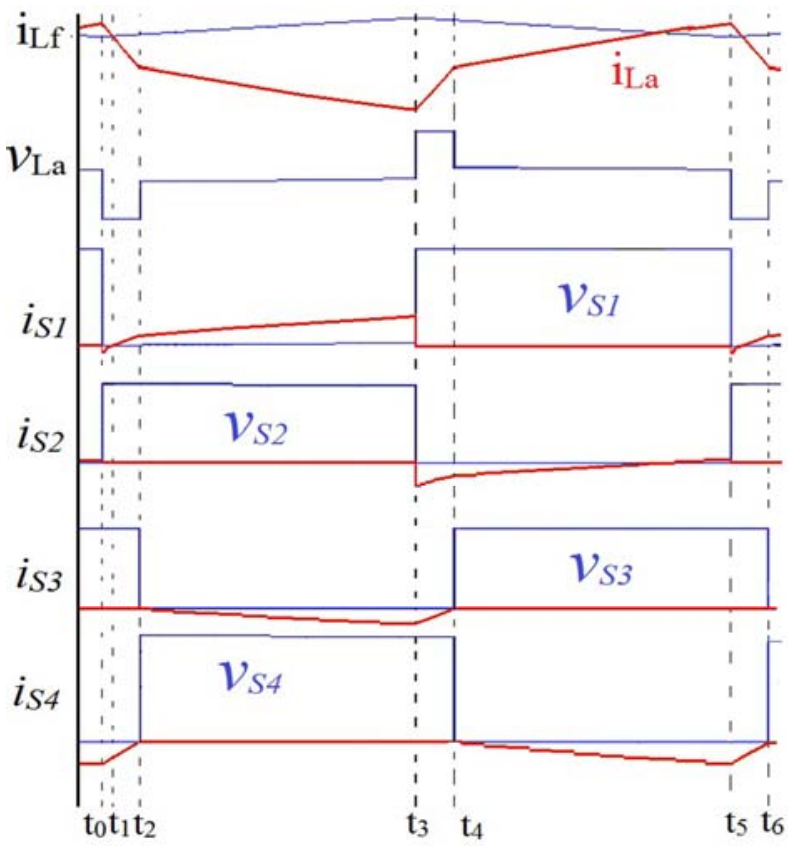

Fig. 2. Key waveforms of boost mode

\section{A. Boost Mode Operation}

Fig. 2 depicts the chief waveform of boost mode. The operation of this converter is from time interval $t_{0}-t_{6}$, current flow schematics were shown in Fig.3 (a) to Fig.3 (e).

At initial state $\mathrm{t}_{0}$, the MOSFETs $S_{1}, S_{2}$ are in turn-off condition. From $\mathrm{t}_{0}$, the output diodes of $S_{1}$ and $S_{4}$ are turned-on and whenever the gating signal supplied to the $S_{1}$, which will turn-on under ZVS condition. From the interval $t_{1}$, current of $\left(L_{f}\right)$ is greater than the inductor current $\left(L_{a}\right)$ and $S_{1}$ is turned-on, current flows through the switch $S_{1}$ is equal to output current at $t_{2}$. The switch $S_{4}$ is turned off under ZCS turn off at $t_{2}$. From $t_{2}-t_{3}$, the current of $L_{a}$ reverses and the body diode of $S_{3}$ is turned-on and then $S_{3}$ turned on under ZVS turn-on operation. From $\mathrm{t}_{3}-\mathrm{t}_{4}$ the MOSFETs $S_{1}, S_{3}$ are turned-off and output diodes of $S_{2}, S_{3}$ are in turned-on respectively. At $\mathrm{t}_{3}$, the gating signal is applied to $S_{2}$ and then turned-on under ZVS operation. From pervious stage, the body diode of $S_{4}$ conducts and at $\mathrm{t}_{4}$, the MOSFET $S_{4}$ is turned-on under the ZVS condition. 


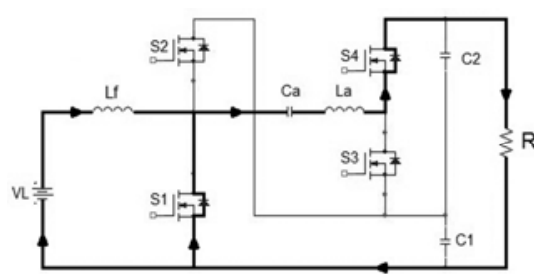

(a)

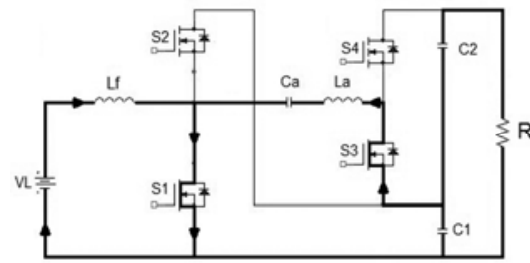

(c)

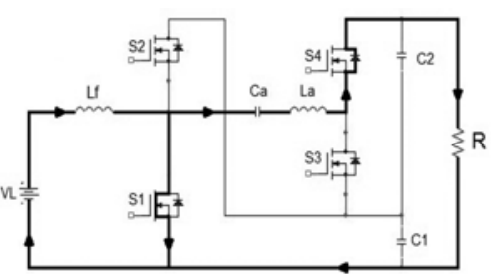

(b)

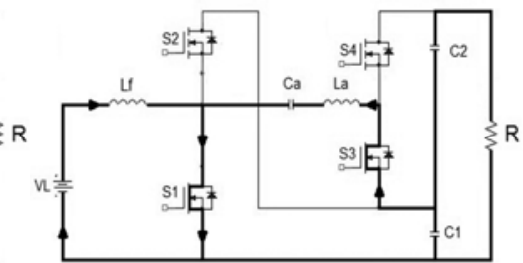

(d)

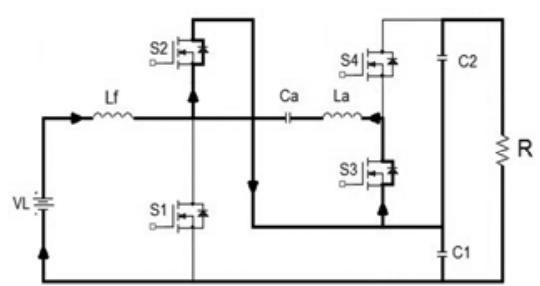

(e)

Fig. 3. Operating stages (a) $t_{0}-t_{1}$ (b) $t_{1}-t_{2}$ (c) $t_{2}-t_{3}$ (d) $t_{3}-t_{4}$ (e) $t_{4}-t_{5}$ : Boost mode

\section{B. Buck Mode Operation}

In buck mode operation all the four MOSFETs are turned-on at different time intervals. In first three stages $S_{1}$, $S_{3}$ are conducting and second three stages $S_{2}, S_{4}$ will conduct. High voltage side is using $S_{3}, S_{4}$ switches with asymmetrical switching. Fig.4. represents the key waveform of buck mode. During $t_{0}-t_{1}$, the MOSFETs $S_{2}, S_{4}$ are turned-off and the diodes of $S_{1}, S_{3}$ are turned-on.

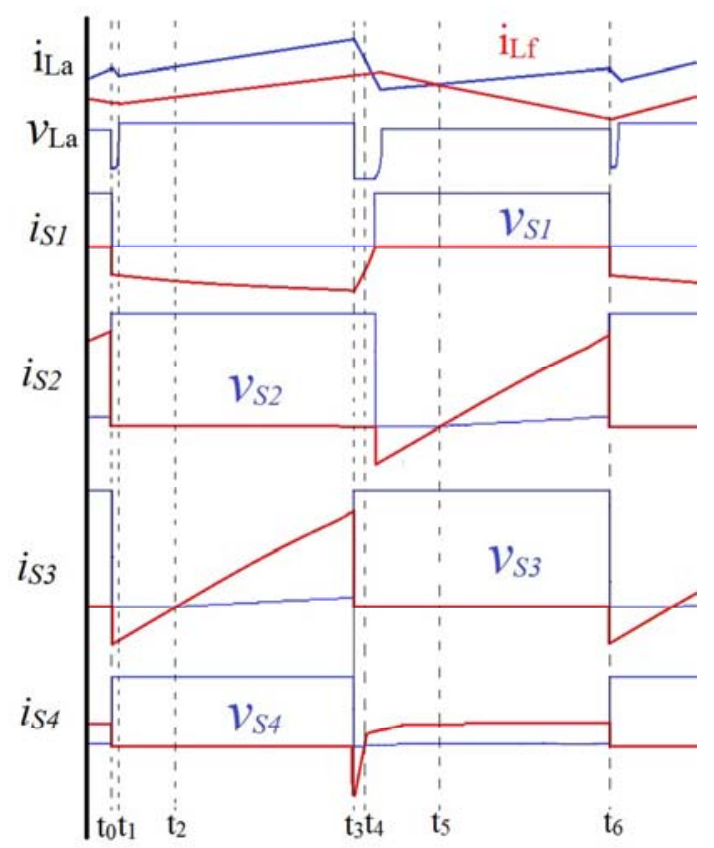

Fig. 4. Key waveforms of buck mode 
At $\mathrm{t}_{1} S_{1}, S_{3}$ are turned-on under the ZVS operation and resonant inductor $\left(L_{a}\right)$ current decreasing smoothly. From $t_{2}-t_{3}$, the switches $S_{1}, S_{3}$ are being conducted and resonant inductor $L_{a}$ current is reversed. At $t_{3}$, the switch $S_{3}$ is turned-off in hard-switching condition. And then $S_{1}$ is turned-off in zero current operation at $t_{4}$. The diodes of $S_{1}, S_{4}$ are turned-on and turned-off, respectively. At the end of this interval $t_{4}$, the MOSFET $S_{2}$ is turned-on, which implies that ZVS operation is achieved. From $t_{4}-t_{5}$, the $S_{2}$ is turned-on under the ZVS operation and the current $L_{a}$ is greater than the current of $L_{f}$. During the interval $\mathrm{t}_{5}-\mathrm{t}_{6}$, the $L_{a}$ current gradually increasing towards the output current and the MOSFETs $S_{2}, S_{4}$ are turned-off at time $t_{6}$. Fig 5 (a) to Fig.5 (f) shows the current flow schematics of buck mode from $t_{0}$ to $t_{5}$ intervals.

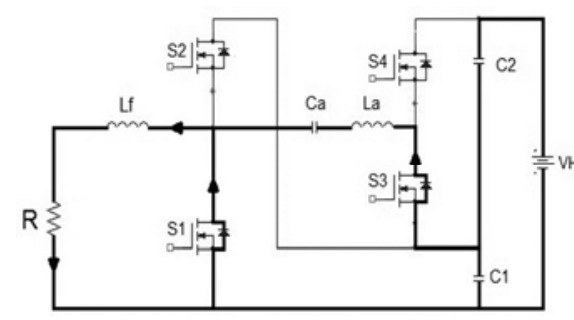

(a)

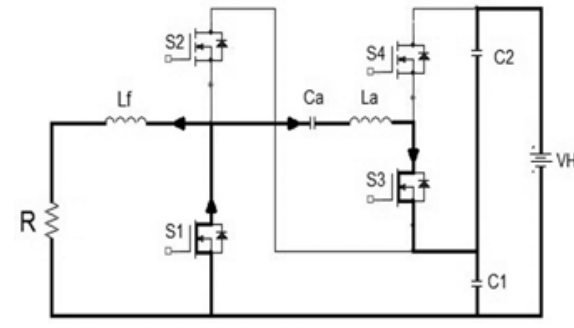

(c)

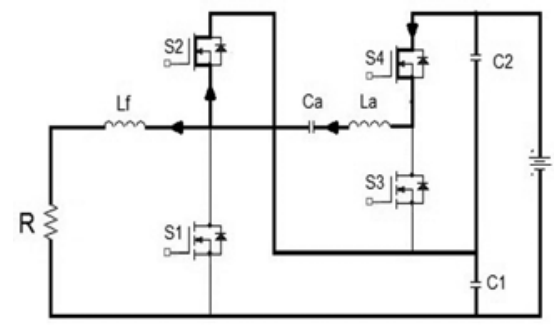

(e)

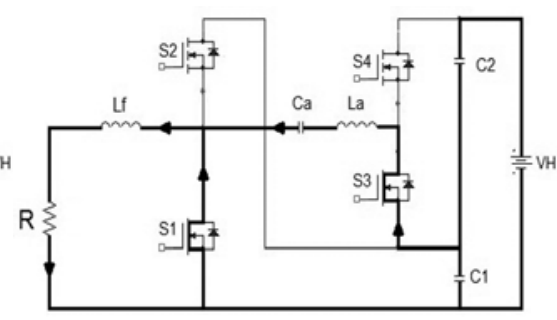

(b)

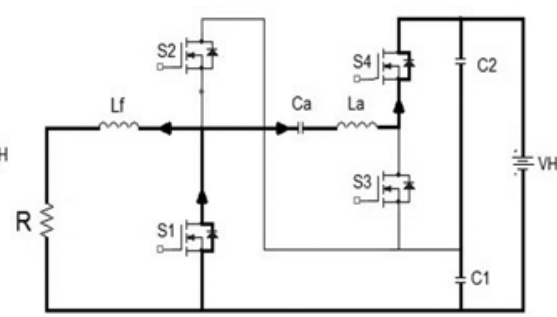

(d)

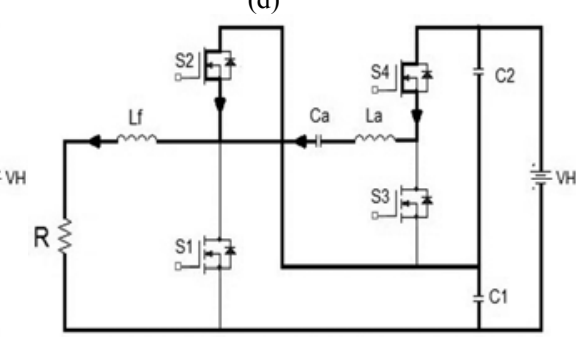

(f)

Fig. 5. Operating stages (a) $t_{0}-t_{1}$ (b) $t_{1}-t_{2}$ (c) $t_{2}-t_{3}$ (d) $t_{3}-t_{4}$ (e) $t_{4}-t_{5}(f) t_{5}-t_{6}$ : Buck mode

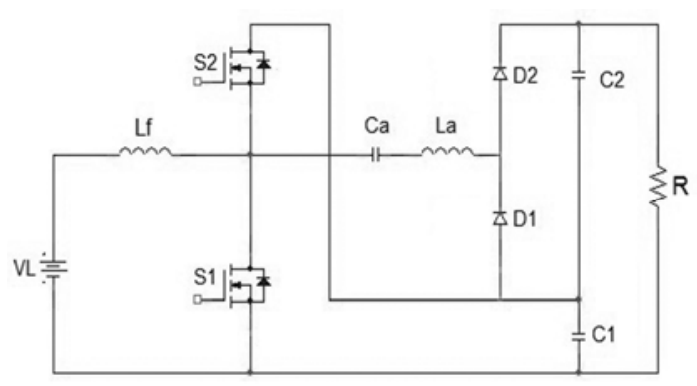

Fig. 6. High step-up DC-DC converter [12]

\section{High Step-up Converter}

Fig.6 depicts the existing topology [12] comprised of a single half-bridge switches $S_{1}-S_{2}$, diode rectifier $\left(D_{1}, D_{2}\right)$. The operation of this topology is divided into two regions, one condition is switching frequency is below the resonance $L_{a}, C_{a}$ and other is switching frequency above the resonant frequency. While converter is operating in below resonance frequency, the $S_{1}$ is turned-on with ZVS operation and the diode $D_{1}$ is turned-on with ZCS condition. And then, the ZCS turned-off condition obtained for diode $D_{1}$. Similarly for a subsequent period, the soft-switching operations ZVS, ZCS are achieved to the $S_{2}$ and diode $D_{2}$, respectively. 


\section{SimUlation RESUlTS \& COMPARATIVE ANALYSIS}

The circuit is designed and simulated using the MATLAB Simulink. Table I shows the simulation parameters considered for bidirectional converter and step-up converter.

TABLE I. Simulation Parameters

\begin{tabular}{|l|c|c|}
\hline \multicolumn{1}{|c|}{ Parameter } & Bidirectional Converter & Step-up Converter \\
\hline Input Voltage $\left(V_{L}\right)$ & $70 \mathrm{~V}$ & $70 \mathrm{~V}$ \\
\hline Output Voltage $\left(V_{H}\right)$ & $250 \mathrm{~V}$ & $250 \mathrm{~V}$ \\
\hline Maximum output Power $\left(P_{o}\right)$ & $1.2 \mathrm{~kW}$ & $800 \mathrm{~W}$ \\
\hline Switching Frequency $\left(f_{s}\right)$ & $30 \mathrm{kHz}$ & $50 \mathrm{kHz}$ \\
\hline Input Inductor $\left(L_{f}\right)$ & $130 \mu \mathrm{H}$ & $50 \mu \mathrm{H}$ \\
\hline Resonant Inductor $\left(L_{a}\right)$ & $13 \mu \mathrm{H}$ & $6 \mu \mathrm{H}$ \\
\hline Resonant Capacitor $\left(C_{\mathrm{a}}\right)$ & $30 \mu \mathrm{F}$ & $2.7 \mu \mathrm{F}$ \\
\hline Output Capacitors $\left(\mathrm{C}_{1}, \mathrm{C}_{2}\right)$ & $470 \mu \mathrm{F}$ & $470 \mu \mathrm{F}$ \\
\hline
\end{tabular}
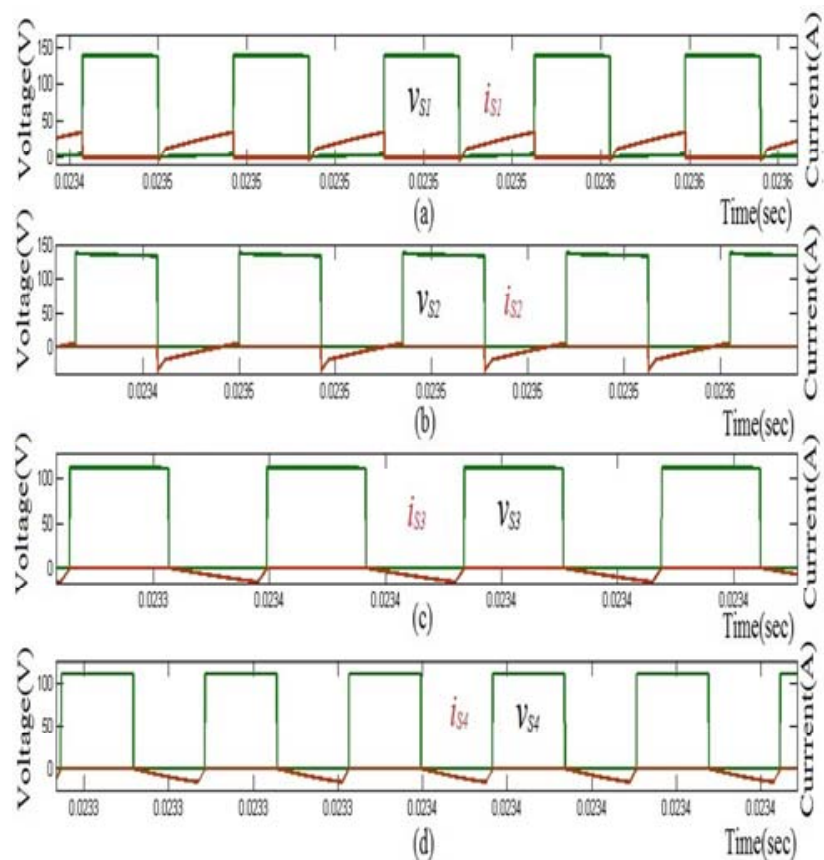

Fig. 7. (a,b,c,d) Simulation waveforms :Boost mode (a) Drain-source voltage $\left(V_{d s}\right) \&$ drain current $\left(i_{d}\right)$ of $S_{1}\left(\right.$ b) Drain-Source Voltage $\left(V_{d s}\right)$ $\&$ drain current $\left(i_{d}\right)$ of $S_{2}(\mathrm{c})$ Drain-source voltage $\left(V_{d s}\right) \&$ drain current $\left(i_{d}\right)$ of $S_{3}(\mathrm{~d})$ Drain-source voltage $\left(V_{d s}\right) \&$ drain current $\left(i_{d}\right)$ of $S_{4}$.

The high gain bidirectional DC-DC converter operates in boost and buck modes, respectively. Simulation analysis observed for boost mode in order to verify the theoretical assumptions. Fig.7 (a,b,c,d) shows the simulated waveforms drain-source voltage and currents of all the MOSFETs $S_{1}, S_{2}$ and $S_{3}, S_{4}$. It is observed the zero voltage switching operation achieved with the all switching devices. Fig. $8(\mathrm{a}, \mathrm{b})$ represents the voltage and current waveforms of $L_{a}$ when converter operating in boost mode. Similarly, simulations are performed on buck mode simulation results of drain-source voltage and current waveforms are depicted in Fig.9 (a,b,c,d). Fig.10 (a,b) represents the current and voltage waveforms of $L_{a}$. The design, simulation analysis observed in two operating conditions for high step-up DC-DC converter. Firstly, simulation analysis made when the converter operating in below the resonance frequency. The resonant inductor $\left(L_{a}\right)$ value $6 \mu \mathrm{H}$ and resonant capacitor $\left(C_{a}\right) 1.5 \mu \mathrm{F}$ has chosen respectively. Fig.11 (a,b) illustrated the voltage and current waveforms of $S_{1} \& S_{2}$. Fig.11(c,d) shows current and voltage waveforms of $L_{a}$. The second condition considered when converter operating above resonant frequency, obtained results were depicted in Fig.12 (a,b) the voltage and current waveforms of $S_{1} \& S_{2}$.Fig.12(c,d) shows the current and voltage waveforms of $L_{a}$. 

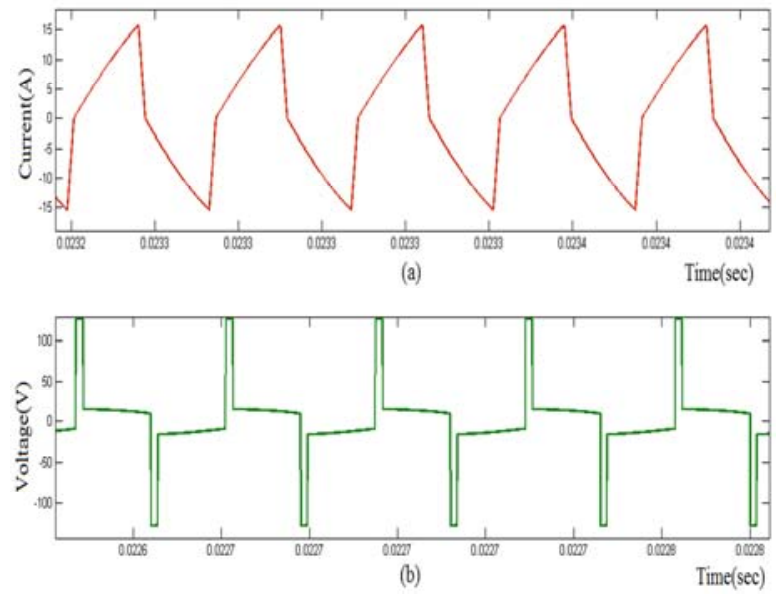

Fig. 8. (a,b) current and voltage waveforms of $L_{a}$ : Boost mode.
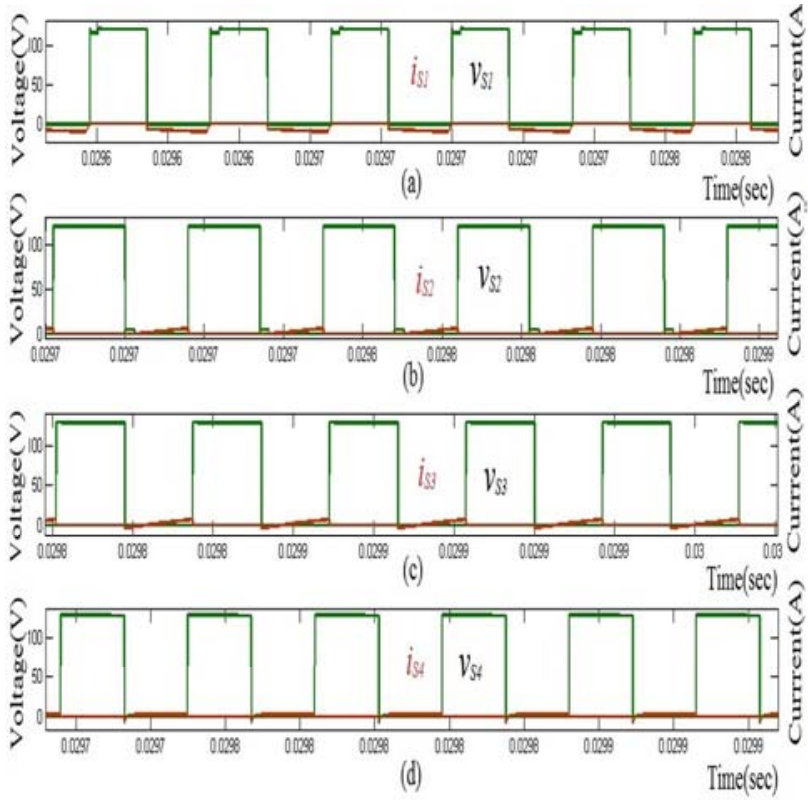

Fig. 9. (a,b,c,d) Simulation waveforms :Buck mode (a) ) Drain-source voltage $\left(V_{d s}\right) \&$ drain current $\left(i_{d}\right)$ of $S_{1}$ (b) Drain-source voltage $\left(V_{d s}\right)$ $\&$ drain current $\left(i_{d}\right)$ of $\left.S_{2}(\mathrm{c})\right)$ Drain-source voltage $\left(V_{d s}\right) \&$ drain current $\left(i_{d}\right)$ of $\left.S_{3}(d)\right)$ Drain-source voltage $\left(V_{d s}\right) \&$ drain current $\left(i_{d}\right)$ of $S_{4}$.
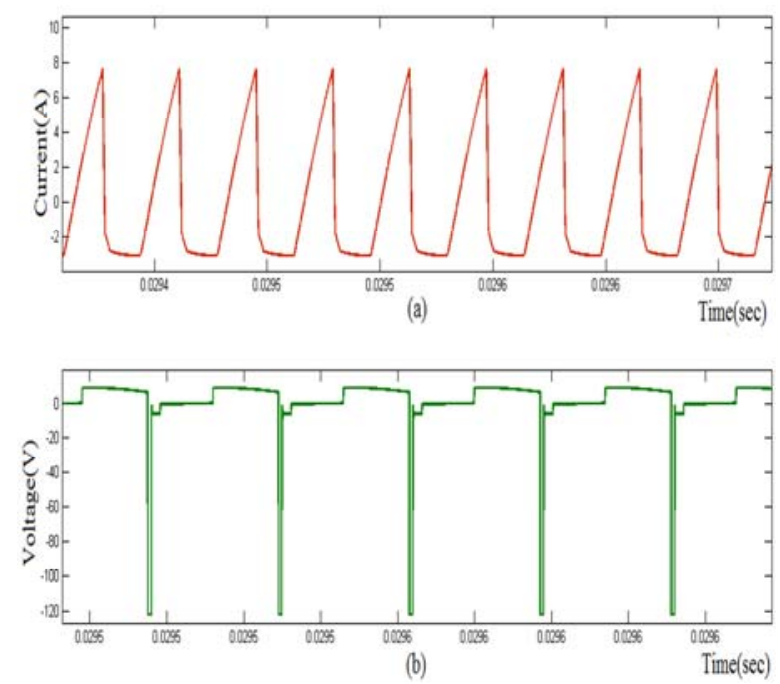

Fig. 10. (a,b) Simulation waveforms of current and voltage of $L_{a}$ : Buck mode. 

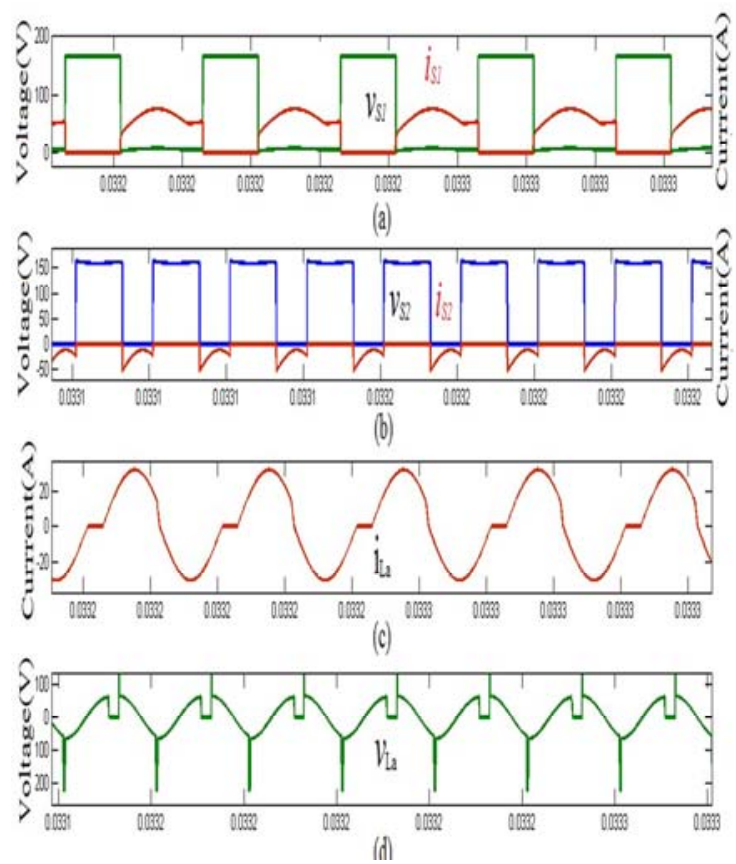

Fig. 11. (a,b,c,d). Simulation waveforms: High Step-up converter (a) Drain-source voltage $\left(V_{d s}\right) \&$ drain current $\left(i_{d}\right)$ of $S_{1}($ b) ) Drain-source voltage $\left(V_{d s}\right) \&$ drain current $\left(i_{d}\right)$ of $S_{2}(\mathrm{c})$ current of $i_{L a}(\mathrm{~d})$ voltage through $V_{L a}:$ Below resonance condition of step up converter.

Table II shows the comparison on various parameters of high gain bidirectional and high step-up DC-DC converters, respectively. Simulated efficiency calculated the function of the output power to the input power for both the converters. The efficiency curves shown in Fig.13 and Fig.14 and the maximum efficiency obtained 99\% at $1.2 \mathrm{~kW}$ output power level for high gain bidirectional converter and $96.5 \%$ at $800 \mathrm{~W}$ output power level for high step-up DC-DC converter, respectively. The lower efficiency obtained $94.8 \%$ at $250 \mathrm{~W}$ for high step-up and $96.7 \%$ at $250 \mathrm{~W}$ for high gain bidirectional converters.
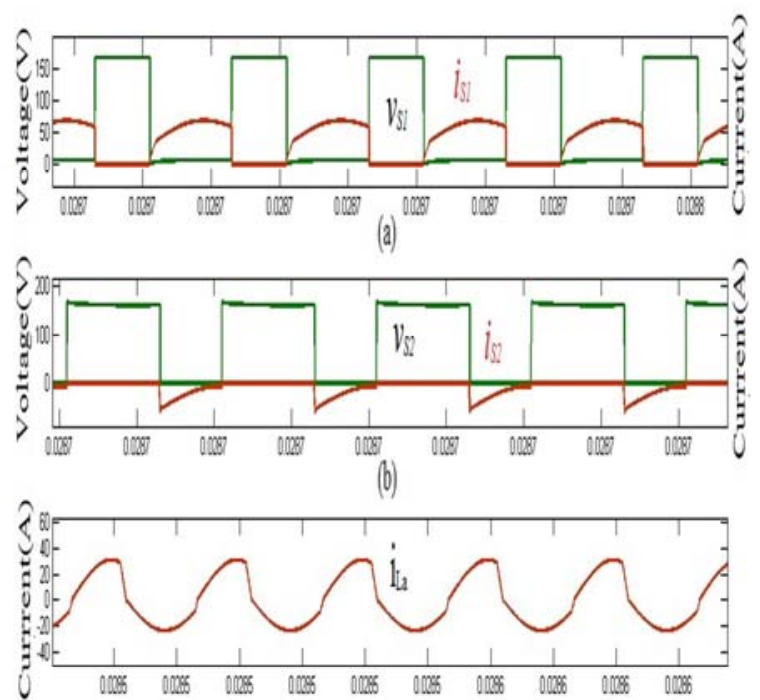

(c)

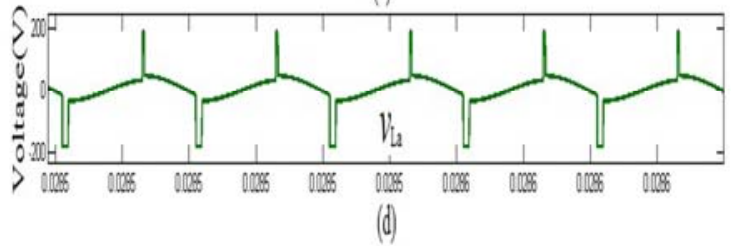

Fig. 12. (a,b,c,d). Simulation waveforms: High Step-up converter (a) Drain-source voltage $\left(V_{d s}\right) \& \operatorname{drain} \operatorname{current}\left(i_{d}\right)$ of $S_{1} S_{1}(\mathrm{~b})$ Drain-source voltage $\left(V_{d s}\right) \&$ drain current $\left(i_{d}\right)$ of $S_{1}$ of $S_{2}(\mathrm{c})$ current of $i_{L a}(\mathrm{~d})$ voltage through $V_{L a}$ : Above resonance condition of step-up converter. 


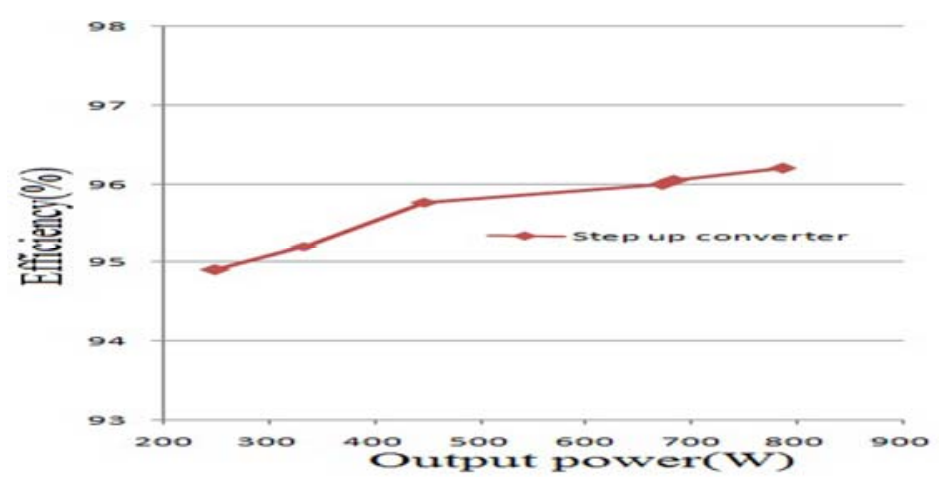

Fig. 13. Simulated efficiency: High Step-up converter

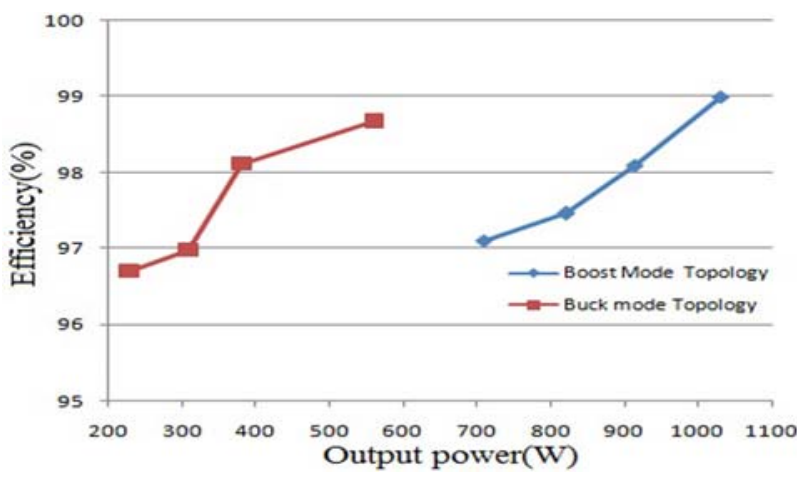

Fig. 14. Simulated efficiency: High gain bidirectional converter

TABLE II. Comparison of Converters

\begin{tabular}{|l|c|c|c|}
\hline \multirow{2}{*}{ Performance parameter } & \multicolumn{2}{|c|}{ Topology[11] } & \multirow{2}{*}{ Topology[12] } \\
\cline { 2 - 3 } & Boost mode & Buck mode & \\
\hline Conduction loss & HIGH & HIGH & LOW \\
\hline Soft switching & ZVS ,ZCS & ZVS ,ZCS & ZVS,ZCS \\
\hline Total no of Components & HIGH & HIGH & LOW \\
\hline No of auxiliary component & 2 & 2 & 2 \\
\hline Simulation conditions & $70 \mathrm{~V}, 1 \mathrm{~kW}, 30 \mathrm{kHZ}$ & $250 \mathrm{~V}, 700 \mathrm{~W}, 30 \mathrm{kHZ}$ & $70 \mathrm{~V}, 800 \mathrm{~W}, 50 \mathrm{kHZ}$ \\
\hline Simulated Efficiency $(\%)$ & 99 & 98 & 97 \\
\hline Applicable power range & $1 \mathrm{~kW}-5 \mathrm{~kW}$ & $1 \mathrm{~kW}-5 \mathrm{~kW}$ & $2 \mathrm{~kW}$ \\
\hline Cost & Costlier & Costlier & Less costly \\
\hline
\end{tabular}

\section{IV.CONCLUSION}

This article presented the comparative simulation analysis on high gain bidirectional and high step-up DC-DC converters, respectively. The operation principles, simulation results, and efficiency analysis are presented as well. The simulation evaluations performed on the MATLAB environment for both converters. The efficiencies of high gain bidirectional converter obtained $99 \%$ at $1.2 \mathrm{~kW}$ and $96.5 \%$ at $800 \mathrm{~W}$ for high step-up DC-DC converters. The cost of the high gain bidirectional converter is high due to increased component count and cost of the step-up converter is low because device count is reduced. Efficiency wise, the high gain bidirectional converter is preferable for high power application and high step-up converter can be applied for low power applications. 


\section{REFERENCES}

[1] M. Beraki, J. P. Trovao, M. Perdigao and F. Machado, "Bidirectional DC-DC Converter Using Variable Inductor Concept for Electric Vehicle Applications," 2016 IEEE Vehicle Power and Propulsion Conference (VPPC), Hangzhou, 2016, pp. 1-6.

[2] M. M. Rahman, M. N. Uddin and M. K. Islam, "Integration of bi-directional DC-DC converter and highly efficient boost converter for electric vehicles applications," 2015 IEEE 11th International Conference on Power Electronics and Drive Systems, Sydney, NSW, 2015, pp. 687-691.

[3] W. Martinez, M. Yamamoto, J. Imaoka, F. Velandia and C. A. Cortes, "Efficiency optimization of a two-phase interleaved boost DCDC converter for Electric Vehicle applications," 2016 IEEE 8th International Power Electronics and Motion Control Conference (IPEMC-ECCE Asia), Hefei, 2016, pp. 2474-2480.

[4] S. Lee, J. Yi, W. Kim and B. H. Cho, "A parallel-series connected four-transformer half bridge DC-DC converter for electric vehicle application," 2013 IEEE ECCE Asia Downunder, Melbourne, VIC, 2013, pp. 711-715.

[5] Dawei He, P. Ntsama, Jinchi Han and T. G. Habetler, "A novel isolated bidirectional DC-DC converter for ultra-capacitor application in hybrid and electric vehicles," IECON 2012 - 38th Annual Conference on IEEE Industrial Electronics Society, Montreal, QC, 2012, pp. $2872-2876$.

[6] S. Cui, D. He, Z. Chen and T. G. Habetler, "A wide input voltage range ZVS isolated bidirectional DC-DC converter for ultracapacitor application in hybrid and electric vehicles," 2012 IEEE International Electric Vehicle Conference, Greenville, SC, 2012, pp. $1-6$.

[7] A. Lachichi and N. Schofield, "Comparison of DC-DC Converter Interfaces for Fuel Cells in Electric Vehicle Applications," 2006 IEEE Vehicle Power and Propulsion Conference, Windsor, 2006, pp. 1-6.

[8] K. Likhitha, S. S. Kumar and G. Kanimozhi, "Isolated DC-DC zero voltage switching converter for battery charging applications," 2016 Biennial International Conference on Power and Energy Systems:

[9] M. Muhammad, M. Armstrong and M. A. Elgendy, "A Nonisolated Interleaved Boost Converter for High-Voltage Gain Applications," in IEEE Journal of Emerging and Selected Topics in Power Electronics, vol. 4, no. 2, pp. 352-362, June 2016.

[10] M. Aamir, S. Mekhilef and H. J. Kim, "High-Gain Zero-Voltage Switching Bidirectional Converter With a Reduced Number of Switches," in IEEE Transactions on Circuits and Systems II: Express Briefs, vol. 62, no. 8, pp. 816-820, Aug. 2015.

[11] M. Kwon, S. Oh and S. Choi, "High Gain Soft-Switching Bidirectional DC-DC Converter for Eco-Friendly Vehicles," in IEEE Transactions on Power Electronics, vol. 29, no. 4, pp. 1659-1666, April 2014.

[12] Y. Park, B. Jung and S. Choi, "Nonisolated ZVZCS Resonant PWM DC-DC Converter for High Step-Up and High-Power Applications," in IEEE Transactions on Power Electronics, vol. 27, no. 8, pp. 3568-3575, Aug. 2012.

\section{AUTHOR PROFILE}

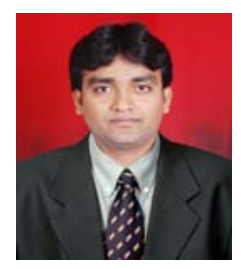

Rajesh Thumma was born in India on $22^{\text {nd }}$ April 1986, received his degrees B.Tech in Electronics and Communication engineering from Sri Kavitha college of engineering Khammam, Telangana, India (Jawaharlal Nehru Technology University, Hyderabad), in 2007, M.Tech from BITS, Khammam, Telangana, India under Jawaharlal Nehru Technology University, Hyderabad in the year 2012. Currently pursuing his PhD in School of Electronics Engineering at KIIT University, Bhubaneswar, India (from 2013). His research area on softswitching DC-DC converters.

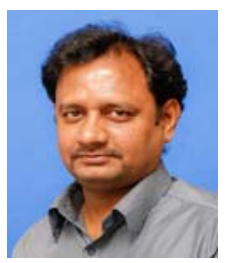

Veera Venkata Subrahmanya Kumar Bhajana was born in India on $4^{\text {th }}$ June 1978 , received his degrees B.E in Electronics and Communication engineering from Sapthagiri college of engineering Dharmapuri, Tamilnadu, India (University of Madras), in 2000, M.E from the P.S.N.A College of engineering and Technology, Dindigul, Tamilnadu, India under Anna University, Chennai in the year 2005 and $\mathrm{PhD}$ in Electrical Engineering from the Bharath University, Chennai, India in 2011. He is previously associated as post-doc researcher in University of West Bohemia, Plzen, Czech Republic during Aug 2013 to June 2015. He is currently working as Associate Professor in the School of Electronics Engineering at KIIT University, Bhubaneswar, India since December 2011.He is also working as a visiting researcher at University of West Bohemia,Pilsen, Czech Republic (from 2016). His key areas of interest is Power Electronics engineering, which includes soft switching DC to DC converters, AC-AC converters, multilevel converters. 